\title{
Analysis on the Willingness and Influencing Factors of the Villagers to Market the Rural Collective Construction Land in Nanhai District of Guangdong Province under the Background of Transformation and Upgrading of Manufacturing Industry
}

\author{
Cairong Wu, Feng Luo \\ Department of Management, Foshan University, Foshan 528000, China
}

\begin{abstract}
By analyzing the cognition and willingness of the villagers in Nanhai district (a big manufacturing city) of guangdong province to the marketing of the rural collective operating construction land, this paper finds out the key factors of the villagers' response to the marketing of the rural collective operating construction land, and puts forward some suggestions on how to promote the villagers' response to the marketing of the rural collective operating construction land. This paper takes villagers from 7 towns in Nanhai District of Guangdong Province as the investigation objects, and effectively gets questionnaires from 596 villagers by means of random investigation. The research methods of descriptive statistics and Logistic regression model are specifically used. The villagers in Nanhai District of Guangdong Province have a strong willingness to market the rural collective operating construction land, among which $63.42 \%$ of the surveyed villagers agree to market the rural collective operating construction land, but $36.58 \%$ of the surveyed villagers still have a weak willingness. There are five key factors that affect villagers' willingness to market rural collective operating construction land: villagers' education level, agricultural dependence, annual household net income, expectation of market effect and view of market risk of agricultural land. In order to improve the willingness of the villagers in Nanhai District of Guangdong Province to enter the market of the rural collective operating construction land, the following four measures can be taken to realize it: First, to improve the villagers' education level; Second, reduce the villagers' dependence on agriculture and increase the annual net income of the villagers' families. Thirdly, the demonstration effect of entering the market should be effectively done to improve the villagers' expectation of the effect of entering the market. Fourthly, the education of popularizing the knowledge of entering the market should be strengthened to guide the villagers to correctly understand the institutional nature of entering the market of agricultural land so as to reduce the risk of entering the market of agricultural land.
\end{abstract}

Keywords: Rural collective productive construction land, the willingness to enter the market, influencing factor, Nanhai District of Guangdong Province, industrialized city

\section{Introduction}

Since the reform and opening up, the rapid development of Nanhai District of Guangdong Province, the restriction effect of land resources is more and more obvious, the optimization of land resources allocation is directly related to the sustainability of social and economic development of Nanhai District of Guangdong Province. As early as 2009, the Nanhai District Government of Guangdong took the lead in implementing the "Three Old" reconstruction project, and constantly explored feasible ways to transfer rural collective operating construction land from practice. However, it was not until February 2015 that China selected 33 pilot areas for rural land system reform, and Nanhai District of Guangdong Province was successfully selected as one of the 33 pilot areas for rural land system reform. Thus, the marketing of rural collective land for operating construction in Nanhai District was truly legalized.

Since 2015, China's rural land reform pilot projects have gradually spread and deepened, and the academic circles have gradually expanded the scope of research on the reform of rural collective operating construction land entering the market. The mode of rural collective construction land market circulation, motivation, the existence ISSN: 0010-8189 
question, the market path selection, intervene intend, influence factors, the market supporting policies, legal system construction, achievements in aspects of income distribution is very rich. Such as huang zhong [1], Wu Cairong [2] study the collective land in the market circulation mode and features. Li Jing [3], Long Feng [4] and others have made a detailed analysis of the reasons for the introduction of rural collective construction land into the market. Luo Yuhui [5], Ma Yanping [6] and Song Yinong [7] studied the problems existing in the marketing of collective operating construction land. Wu Zhenjun [8] has made beneficial exploration on the supporting policies for market entry. Wen Shiyang [9], Cao Xiaohui [10], Lu Jian [11] and others who have studied the legal system construction of entering the market. Shen Wenjin [12], Zhang Wei [13] and others have conducted research on the income distribution of market entry. Zhai Bin [14] is one of the researchers who studied the willingness to enter the market and its influencing factors. At the same time, many scholars have carried out in-depth research on each pilot project in China. Among them, Zhang Ting [15][16] and Gao Xin [17] have studied the marketing of rural collective operating construction land in Nanhai District of Guangdong Province. However, by combing the literature, it is found that there are few researches on the marketing of rural collective operating construction land in Nanhai District of Guangdong Province, and on the understanding, willingness and influencing factors of the villagers' marketing from the perspective of their micro subjects. Therefore, from the perspective of the micro-subject of the villagers, this paper studied and understood the villagers' cognition and willingness to enter the market of the collective operating construction land through questionnaire and Logistic model construction, and explored the influencing factors of the villagers' response to the market of the collective operating construction land. This will provide reference for the further marketing of collective operating construction land in Nanhai District of Guangdong Province.

\section{Regional Overview}

Nanhai District of Foshan City of Guangdong Province is located in the middle of the Pearl River Delta, the northeast of Foshan City, close to Guangzhou City, under the jurisdiction of 6 towns, 1 sub-district, 286 villages (communities), as of the end of 2019, registered population of 1.6006 million, permanent resident population of 3.0317 million, an area of 1073.82 square kilometers, the comprehensive strength of the top in China. In 2019, the gross domestic product (GDP) of the Nanhai District reached 317.662 billion yuan, comparable to that of a western province and is a typical developed region. With the rapid development of industrialization, urbanization, informatization and agricultural modernization, the collective economy in Nanhai District has expanded rapidly. The disposable income of collective economic organizations exceeds 5.6 billion yuan, and the share dividend exceeds 2.7 billion yuan. The per capita net income of rural residents is 16,673 yuan, and the per capita share dividend of 760000 members and shareholders is 3516 yuan. The total income of 197 villages exceeded 100 million yuan, accounting for more than 70 percent of the total.

There are three reasons why this paper chooses Nanhai District of Guangdong Province as the research area. First, Nanhai District is the only selected pilot city in Guangdong. As early as the 1990s, with the rapid development of township enterprises, Nanhai District to release a large number of collective land for operating construction and quietly entered the market with the local government turning a blind eye. Second, the Nanhai District, located in the eastern coastal area, is the pioneer of reform in Guangdong Province and even the whole country. The problem of rural collective land for operating construction is very prominent, and it is the epitome of the rural land system reform in relatively developed areas such as Pearl River Delta. Third, the economic development of Nanhai District ranks in the forefront of county economy in Guangdong Province, and it is a typical industrialized city and relatively developed region. Therefore, it is of great significance to pilot the legalization of collective land for operating construction in Nanhai District. Based on the above three points, the practice of rural collective operating construction land in Nanhai District of Guangdong Province is very representative.

\section{Data Sources and Descriptive Statistics of Samples}

\subsection{Data sources}


The specific survey sites and samples of this survey were all over the towns and streets of Nanhai District of Guangdong. According to the development status and geographical location of villages, the Nanhai District can be divided into three regions: the eastern region, the central region and the western region. The villages selected from each region are shown in Table 1.The survey was conducted from July to September 2019. A total of 650 questionnaires were sent out, 600 were actually received and 596 were effectively collected, with an effective rate of $92 \%$.Among them, 311 questionnaires were collected in the eastern area, including Guicheng Street, Dali Town and Lishui Town. In the central region, 104 questionnaires were collected from Shishan Town. In the western region, which included Xiqiao, Danzao and Jiujiang towns, 181 points were collected. In order to ensure the reliability of the survey data, the whole process was obtained from household surveys by the members of the research group. The survey content is divided into two parts: one is about the "basic information of villagers", such as age, education, income sources, etc.; Second, the attitude, cognition and willingness of the collective operating construction land.

Table 1 Distribution of villages and samples in the Nanhai District of Guangdong Province

\begin{tabular}{|c|c|c|c|c|}
\hline $\begin{array}{c}\text { Three areas of } \\
\text { Nanhai } \\
\text { District of } \\
\text { Guangdong }\end{array}$ & $\begin{array}{l}\text { The town } \\
\text { (street) }\end{array}$ & village & $\begin{array}{c}\text { sample number } \\
\text { of each town } \\
\text { and street }\end{array}$ & $\begin{array}{c}\text { sample } \\
\text { number of } \\
\text { each area }\end{array}$ \\
\hline \multirow{3}{*}{$\begin{array}{l}\text { the eastern } \\
\text { region }\end{array}$} & $\begin{array}{l}\text { Guicheng } \\
\text { street }\end{array}$ & $\begin{array}{c}\text { Xiaxi village, Diebei village, Beiyue village, } \\
\text { Nanyue village }\end{array}$ & 133 & \multirow{3}{*}{311} \\
\hline & Dali town & $\begin{array}{l}\text { Daheng village, Xiaobu village, Xibian } \\
\text { village, Fengxi village, Huangqi village, } \\
\text { Shangheng village }\end{array}$ & 90 & \\
\hline & $\begin{array}{l}\text { Lishui } \\
\text { town }\end{array}$ & Wuyi village, Deshegnvillage & 88 & \\
\hline $\begin{array}{l}\text { The middle } \\
\text { area }\end{array}$ & $\begin{array}{l}\text { Shishan } \\
\text { town }\end{array}$ & $\begin{array}{c}\text { Liangtang village, Xiaotang village, } \\
\text { Dongbian village }\end{array}$ & 104 & 104 \\
\hline \multirow[b]{2}{*}{$\begin{array}{l}\text { the western } \\
\text { region }\end{array}$} & $\begin{array}{l}\text { Jiuijang } \\
\text { town }\end{array}$ & $\begin{array}{l}\text { Heqign village, Yannan village, Zhennan } \\
\text { village, Qingshou village, Shangzhogn } \\
\text { village, Shatoubei village, Xiangming } \\
\text { village, Shangdong village, Shazhui village }\end{array}$ & 32 & \multirow[b]{2}{*}{181} \\
\hline & $\begin{array}{l}\text { Danzhao } \\
\text { town }\end{array}$ & $\begin{array}{c}\text { Dongsheng village, Xiangang village, } \\
\text { Danzhao village, Shajiao village, } \\
\text { Dawo village, Liansha village, Nansha } \\
\text { village, Xinanvillage, Shilian village, } \\
\text { Laobian village, Liangdeng village, Xicheng } \\
\text { village, Donglian village, Xiaanvillage, } \\
\text { Yinhe village, } \\
\text { Langxin village, Jianshe village, Xilian } \\
\text { village } \\
\text { Haizhou village, Xintian village, Baidong } \\
\text { village, Huaxia village, Jian village, Shilong } \\
\text { village, Pingsha village, Qixing village }\end{array}$ & 66 & \\
\hline
\end{tabular}

3.2 Descriptive statistics of samples

3.2.1 Description of basic information and data of interviewed villagers in Nanhai District of Guangdong

The age and gender statistics of the villagers surveyed in this questionnaire are shown in Table 2 below. It can be

ISSN: 0010-8189 
seen from Table 2 that the proportion of male and female in the surveyed villagers is the same.47.48\% of the surveyed villagers were under the age of 30;30 to 40 years old accounted for $13.42 \% ; 40$ to 50 years old accounted for $13.59 \%$;50 to 60 years old accounted for 8.89\%; Sixty years old and above accounted for 16.61\%.The educational level of the surveyed villagers: junior college or above accounted for $40.44 \%$; High school or technical secondary school accounted for $18.46 \%$; Junior high school accounted for $19.3 \%$;Primary schools accounted for $21.81 \%$.It can be seen that nearly $60 \%$ of the surveyed villagers in Nanhai of Guangdong Province are senior high school or above, indicating that the villagers in Nanhai of Guangdong Province have a relatively high level of education.

Table 2 Basic information of the interviewed villagers in Nanhai of Guangdong

\begin{tabular}{cccc}
\hline \multirow{2}{*}{ item } & category & $\begin{array}{c}\text { frequent and } \\
\text { continuous }\end{array}$ & percentage \\
\hline \multirow{2}{*}{ gender } & male & 298 & $50.0 \%$ \\
& female & 298 & $50.0 \%$ \\
& Under the age of 30 & 283 & $47.48 \%$ \\
age & 30 to 40 years old & 80 & $13.42 \%$ \\
& 40 to 50 years old & 81 & $13.59 \%$ \\
& 50 to 60 years old & 53 & $8.89 \%$ \\
Age 60 and above & 99 & $16.61 \%$ \\
education & Primary school & 130 & $21.8 \%$ \\
& Junior high school & 115 & $19.3 \%$ \\
& High school or technical & & $18.46 \%$ \\
& secondary school & 110 & $40.44 \%$ \\
annual & College degree or above & 241 & \\
household & 20000 yuan and below 20000 & & $29.19 \%$ \\
income & yuan & 174 & $16.95 \%$ \\
& 21000-40000 & 101 & $19.13 \%$ \\
& 41000-60000 & 114 & $34.73 \%$ \\
\hline
\end{tabular}

The annual household income of the surveyed villagers is shown in Table 2. The frequency of the villagers with an income of 61000 or above is 207 , accounting for $34.73 \%$, which accounts for the largest proportion. 174 frequency of 20000 yuan and below, accounting for $29.19 \%$; The frequency of 21000 to 40000 is 101 , accounting for $16.95 \%$; The frequency of 41000 to 60000 is 114 , accounting for $19.13 \%$.According to the survey results, $53.86 \%$ of the interviewed villagers' families have an annual income of more than 40000 yuan, which is in line with the economic development of Nanhai rural areas in Guangdong Province.

3.2.2 The recognition degree of villagers to the marketing of rural collective operating construction land We set the question "How much do you know about land policy?" to understand the villagers' familiarity with the country's current land policies, systems and laws. We set the "do not understand, understand better and know " three options to choose from, villagers were selected as follows: the number of 318 people, 140 people, 138 people, accounted for, in turn, was $53.36 \%, 23.49 \%, 23.15 \%$, villagers wholly at "not know" more than half, this shows that Nanhai government popularity is still fairly rural land policy is not enough, the villagers along in a passive state in land system reform.

In addition, we set the question "What is your expectation of the market effect of rural collective operating construction land?" to understand the effect of villagers on the marketing of rural collective operating construction land.130,301 and 165 villagers chose "no effect, to be observed and effective" in turn, accounting for $21.81 \%$, $50.5 \%$ and $27.68 \%$, respectively. According to the survey results, more than half of the interviewed villagers believe that the effect of the marketing of rural collective operating construction land is to be observed, indicating

ISSN: 0010-8189 
that the villagers' expectation of the effect of the marketing of rural collective operating construction land is uncertain.

3.2.3 Villagers' cognition of the risk of rural collective construction land entering the market

We set the topic "whether the market entry of collectively-owned construction land will cause risks" to understand Nanhai villagers' understanding of the market entry risks of collectively-owned construction land, there were 128,240 and 228 people who chose "no risk, difficult to predict and inevitable risk", the proportion was $21.48 \%$, $40.27 \%$ and $38.26 \%$ respectively. Nearly 80 per cent of villagers said it was "unpredictable" and "risky".

3.2.4 Villagers' cognition of the income distribution of rural collective productive construction land in the market We set the question "Who do you think should be the biggest beneficiary of rural collective operating construction land?" "And" What do you think should be the subject of land appreciation income distribution?" to understand the villagers' cognition of the beneficiaries of the value-added income after the land is put into the market. For the two questions, there are four options of "villagers, village collectives, local government and others" respectively. For the first question, 216, 160, 124 and 96 people choose it, accounting for $36.24 \%, 26.85 \%, 20.81 \%$ and $16.11 \%$ respectively. The number of people who chose the second question was 299, 119, 63 and 115 respectively, accounting for $50.17 \%, 19.97 \%, 10.57 \%$ and $19.3 \%$ respectively. Can be seen from the results of the survey, the villagers are surveyed said villagers and village collective as the major beneficiaries and the main body, this shows that the villagers' cognitive problems of the rural collective business construction land ownership is in place, so Nanhai district of Guangdong in promoting the rural collective management in the process of the construction land market must be pay attention to the subject status of the villagers and the village collective.

3.2.5 The willingness of the villagers to enter the market for the rural collective productive construction land In order to grasp the willingness of the villagers to enter the market, we set the question "whether they are willing to enter the market" to test. The results showed that 218 people chose "no", accounting for 36.58\%; 378 people choose "yes", accounting for $63.42 \%$.On the whole, the villagers have a strong willingness to market the rural collective operating construction land, the support rate is more than $60 \%$.

\section{Analysis on the Influencing Factors of Villagers' Response to the Marketing of Rural Collective Operating Construction Land}

\subsection{Index selection}

\subsubsection{Selection of dependent variables}

In the questionnaire survey, the paper selects villagers' willingness as the dependent variable, and measures villagers' willingness to market the rural collective operating construction land by setting the topic "whether you are willing to market the collective operating construction land of your village". The "willing" is assigned to 1, and the "unwilling" is assigned to 0.

\subsubsection{Selection of independent variables and direction assumption}

There are many factors that affect the willingness of villagers to market the rural collective operating construction land, and this paper will measure it from four dimensions: villagers' own characteristics, family characteristics, their understanding of the policy of marketing the rural collective operating construction land and their expectation of the effect of marketing. The dimensions of villagers' own characteristics include four items: education background, age, education status and risk preference; The dimension of family characteristics includes three items: agricultural dependence, average annual household net income and the geographical location of the village where the family lives; Through the topic "how much do you know about the land policy" to understand the villagers' understanding of the policy? By setting the topic "What is your expectation of the effect of rural collective operating construction land entering the market?" to understand the market effect expectations. By reading a lot of existing research results and referring to relevant theories on the market transfer of rural collective operating construction land, and combining with the field investigation of this research group, we propose 9 hypotheses on

ISSN: 0010-8189 
The first is the direction of the influence of the "gender" of villagers on the willingness of rural collective operating construction land to market. According to the existing research results, gender is difficult to determine the willingness of rural collective operating construction land to market, so it is assumed that its direction is uncertain. Then it is the influence direction of "age" on the willingness of rural collective operating construction land to enter the market. Generally speaking, young villagers are more likely to accept new things and new ideas than older villagers. Therefore, we assume that older villagers are less willing to accept the marketing of rural collective operating construction land, so the direction is negative.

The third is the influence direction of "education level" on the willingness of rural collective operating construction land to enter the market. Generally speaking, the more educated the villagers are, the more likely they are to accept new things, new ways, new systems and new ideas. Therefore, we assume that the more education villagers receive and the higher their education level, the stronger their willingness to accept rural collective operating construction land into the market is, so the direction is positive.

The fourth is the influence direction of "risk preference" on the willingness of rural collective operating construction land to market. Generally, risk preference can be divided into three types: risk preference, risk neutral and risk aversion. In general, villagers with a strong risk preference are more willing to try new things and make corresponding behaviors. Therefore, we assume that villagers with a strong risk preference are more willing to try to market rural collective operating construction land, so the direction is positive.

The fifth is the direction of the influence of "agricultural dependence" on the willingness of rural collective operating construction land to enter the market. There are some similarities between "agricultural dependence" at the national level and that at the household level.. The former refers to the degree of dependence or dependence of a country or region's economic and social development on agricultural development, while the latter refers to the greater proportion of agricultural income in a family's income. The more dependent a household is on agriculture, the more dependent it is on rural construction land. In other words, the more dependent a household is on agriculture, the less willing it is to try to market rural collective operational construction land. Therefore, the direction is negative.

The sixth is the direction of the influence of "average annual household net income" on the willingness of rural collective operating construction land to enter the market. For families with lower "average annual net household income", economic constraints will promote villagers' willingness to enter the market for rural collective operating construction land, otherwise, the willingness to enter the market is low, so the direction is negative.

The seventh is the direction of the influence of "the geographical location of the family village" on the willingness of rural collective operating construction land to enter the market. Nanhai District of Guangdong Province is located in the center of the Pearl River Delta. Its economic development is strong, but the regional development is unbalanced. The economic and social development levels of towns and streets in different geographical locations in the east, middle and west of the Nanhai District are quite different. In the east, close to Guangzhou, the regional economic development is relatively good, and the land value of farm collective construction land is higher, so the villagers are more eager to master the independent control of the land. Villagers in the central and western parts of the Nanhai District, whose families are located in villages with poor economic development, are more inclined to market collective land for operating construction if the land value of the collective land for operating construction is lower. Therefore, the direction is positive.

The eighth is the direction of the influence of "villagers' understanding of land market policy" on the willingness of rural collective operating construction land to market. Generally speaking, the higher the villagers' understanding of the market entry policy, the easier they are to recognize the advantages and disadvantages of the market entry of

ISSN: 0010-8189 
rural collective operating construction land, and the more likely they are to increase their response to the market entry. Then, the deeper the villagers' understanding of the market-entry policy, the stronger their willingness to market-entry of rural collective operating construction land. Therefore, the direction is positive.

The ninth is the direction of the influence of "villagers' expectation of the effect of land marketing" on the willingness of rural collective operating construction land marketing. The higher the villagers' expected satisfaction with the effect of entering the market, the more obvious they realize that entering the market may bring about the increase of farmers' income and the effect of rural development, the stronger their willingness to accept it. Then, the higher the villagers' expected satisfaction with the effect of market entry, the stronger their willingness to market the rural collective operating construction land, so the direction is positive.

The specific variable type, variable name, variable assignment and direction of influence of hypothesis are shown in Table 3:

Table 3 Variable names, assignment definitions, and assumed influence directions

\begin{tabular}{|c|c|c|c|c|}
\hline $\begin{array}{l}\text { types of } \\
\text { variables }\end{array}$ & variable name & variable assignment and definition & $\begin{array}{l}\text { expected } \\
\text { direction }\end{array}$ & $\begin{array}{c}\text { assumed } \\
\text { sequence } \\
\text { number }\end{array}$ \\
\hline \multirow[t]{6}{*}{$\begin{array}{l}\text { dependent } \\
\text { variable }\end{array}$} & $\begin{array}{c}\text { the } \\
\text { willingness to }\end{array}$ & unwilling $=0 ;$ willing to $=1$ & & \\
\hline & gender & male $=1 ;$ female $=2$ & not sure & 1 \\
\hline & age & $\begin{array}{l}<30=1 ; 30-40=2 ; 40-50=3 ; 50-60=4 ; \text { Age } 60 \\
\text { and older }=5\end{array}$ & negative & 2 \\
\hline & education & $\begin{array}{l}\text { primary } \quad \text { school=1;Junior } \quad \text { high } \\
\text { school=2;High } \\
=3 \text { School or Technical } \\
=3 \text { College degree and above }=4\end{array}$ & positive & 3 \\
\hline & $\begin{array}{l}\text { risk appetite } \\
\text { into the } \\
\text { market }\end{array}$ & $\begin{array}{l}\text { not willing to try }=1 ; \text { On the sidelines }=2 \\
\text { Willing to try }=3\end{array}$ & positive & 4 \\
\hline & $\begin{array}{l}\text { agricultural } \\
\text { dependence }\end{array}$ & $\begin{array}{l}\text { Agriculture }=1 ; \text { Part-time business mainly in } \\
\text { agriculture }=2 ; \\
\text { Part-time } \quad \text { business mainly } \\
\text { non-agricultural=3;Non-agricultural }=4\end{array}$ & negative & 5 \\
\hline \multirow[t]{6}{*}{$\begin{array}{l}\text { independen } \\
\text { t variable }\end{array}$} & $\begin{array}{l}\text { Annual net } \\
\text { household } \\
\text { income }\end{array}$ & $\begin{array}{l}20000 \text { yuan and below } \\
=1 ; 21000-40000 \text { yuan }=2 ; 41000-60000 \text { yuan }= \\
3 ; \text { More than } 61000 \text { yuan }=4\end{array}$ & positive & 6 \\
\hline & $\begin{array}{l}\text { farmers' } \\
\text { understanding } \\
\text { of land } \\
\text { policies }\end{array}$ & $\begin{array}{l}\text { incomprehension }=1 \text {; general } \\
\text { understanding }=2 ; \text { understand }=3\end{array}$ & positive & 7 \\
\hline & $\begin{array}{l}\text { the villagers' } \\
\text { expectation of } \\
\text { the effect of } \\
\text { rural }\end{array}$ & $\begin{array}{l}\text { No effect }=1 ; \text { Remains to be seen }=2 ; \\
\text { Effective }=3\end{array}$ & & \\
\hline & $\begin{array}{l}\text { collective } \\
\text { operating } \\
\text { construction }\end{array}$ & & positive & 8 \\
\hline & $\begin{array}{l}\text { land entering } \\
\text { the market }\end{array}$ & & & \\
\hline & the & the eastern region (guicheng, lishui, dali) & positive & 9 \\
\hline
\end{tabular}




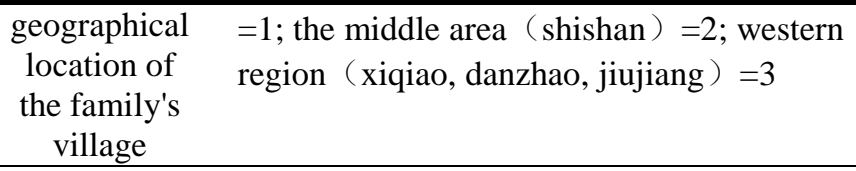

\subsection{Model establishment}

The willingness of villagers to enter the market for rural collective productive construction land can be divided into "willing" or "unwilling", which is a duality problem, and the Logistic regression model is an appropriate tool to solve the duality problem. According to the theoretical basis of binary choice, the Logistic regression model is essentially a logical probability distribution function. Therefore, we set the villagers' "willingness" as the dependent variable and assign values of "1" and "0", representing the villagers' "willingness" and "unwillingness". We construct a binomial logistic regression model to analyze the influencing factors of villagers' willingness to market collective operating construction land. The Logistic regression formula is as follows:

$$
\begin{gathered}
p(y=1)=\beta_{1} x_{1}+\ldots+\beta_{m} x_{m}+b+\varepsilon_{i} \\
\log i t(p)=\ln \left(\frac{p}{1-p}\right)=\beta_{1} x_{1}+\ldots+\beta_{m} x_{m}+b+\varepsilon_{i}
\end{gathered}
$$

$\mathrm{P}$ represents the villagers' willingness to market the rural collective land for operating construction, and 1-P represents the villagers' reluctance to market the rural collective land for operating construction. $\frac{p}{1-p}$ is the ratio, and $\ln \left(\frac{p}{1-p}\right)$ is the logarithm of the ratio. $\beta$ is the parameter to be estimated; $x_{m}$ is the explanatory variable; $\varepsilon_{i}$ is the error term.

\subsection{Model estimation and result analysis}

Logistic regression model of SPSS19.0 software was adopted and Enter method was selected to obtain Cox\&Snell $\mathrm{R}$ square of 0.153 and Nagelkerke $\mathrm{R}$ square of 0.210 in this paper. The parameters were in line with the operation requirements of the model, and the estimated coefficients of each parameter also met the economic significance, indicating that the model constructed in this paper had good effect and high credibility. The specific operation results are shown in Table 4.

Table 4 Model estimation results

\begin{tabular}{ccccccc}
\hline variable name & B & S.E, & Wals & df & Sig. & Exp (B) \\
\hline gender & 0.083 & 0.191 & 0.190 & 1 & 0.663 & 1.087 \\
age & 0.102 & 0.068 & 2.233 & 1 & 0.135 & 1.107 \\
Education level & 0.221 & 0.091 & 5.930 & 1 & $0.015^{*}$ & 1.247 \\
$\quad \begin{array}{c}\text { Agricultural } \\
\text { dependence }\end{array}$ & -0.226 & 0.083 & 7.501 & 1 & $0.006^{* *}$ & 1.254 \\
Annual net household & 0.168 & 0.082 & 4.187 & 1 & $0.041^{*}$ & 1.183 \\
$\quad$ income & & & & & & \\
Policy understanding & -0.010 & 0.125 & 0.006 & 1 & 0.938 & 0.990 \\
Expectation of effect & 0.417 & 0.154 & 7.300 & 1 & $0.007^{* *}$ & 1.517 \\
$\quad$ Risk appetite & 0.412 & 0.136 & 9.190 & 1 & $0.002^{* *}$ & 1.510 \\
$\quad$ Family location & -0.206 & 0.129 & 2.560 & 1 & 0.110 & 0.814 \\
$\quad$ constant & -2.845 & 0.478 & 35.447 & 1 & 0.000 & 0.058 \\
\hline
\end{tabular}

Note: "*" is significant at $5 \%$ level, and "**" means significant at $1 \%$ level. 
By table 4 regression result, the education level, agricultural dependence, family year income, farmers to the rural collective operational effect of construction land market expectations, the market risk preference and so on five variables are passed the test of significance, among them, the education level and family year income $\mathrm{P}$ value is less than 0.05 , significant at the 5\% level, the corresponding coefficient of 0.221 and 0.168 . The $\mathrm{P}$ values of agricultural dependence, expectation of the market effect of rural collective operating construction land and market risk preference are all less than 0.01 , indicating that they are significant at the $1 \%$ level, and the corresponding coefficients are 0.226, 0.417 and 0.412.Therefore, Hypothesis 3, 4, 5, 6, and 8 in Table 3 are all valid, while Hypothesis 1, 2, 7, and 9 are not significantly verified, that is, the variables such as gender, age, knowledge of policy, and family geographical location are not significant.

\section{Research Conclusions and Policy Recommendations}

In conclusion, although the villagers in Nanhai of Guangdong Province generally have a high willingness to enter the market for land, there is still a large room for improvement. Through questionnaire survey and model construction from villagers' micro point of view, this paper concludes that there are five key factors influencing villagers' willingness to market rural collective operating construction land in Nanhai of Guangdong Province, which are villagers' education level, agricultural dependence, annual household net income, effect expectation of market entry and their perception of agricultural land market risk. To this end, we put forward the following countermeasures and suggestions, hoping to provide reference for the smooth promotion of the marketing of rural collective operating construction land in the Nanhai of Guangdong, and also provide experience for the marketing of rural collective operating construction land in other pilot cities in China.

5.1 Improve the educational level of villagers. Through further improving the education level of the villagers in Nanhai of Guangdong Province, the villagers are more likely to accept new things, new ways, new systems and new ideas, as well as more accurately view the trend of rural collective operating construction land entering the market, so as to be more willing to enter the market of rural land.

5.2 Reduce villagers' dependence on agriculture and improve the annual net income of villagers' families. Nanhai of Guangdong Province is a typical industrialized city, where the villagers' dependence on agriculture is relatively low and the annual net income of the villagers' families is relatively high, but there is still room for improvement. In general, reducing villagers' dependence on agriculture can be achieved by further accelerating the process of urban-rural integration, and more fundamentally, non-agricultural employment of villagers can be achieved to a greater extent. In the process of non-agricultural employment, the annual net income of the villagers' families is also increased, thus improving the willingness of the villagers in Nanhai of Guangdong Province to enter the market for land.

5.3 Make the demonstration effect of entering the market well and improve the villagers' expectation of the effect of entering the market. Through increasing publicity efforts, the villages that have done well in entering the market are reported, and the demonstration effect of entering the market of rural collective operating construction land is emphasized, so as to improve the villagers' expectation of the effect of entering the market.

5.4 Strengthen the popularizing education of market access knowledge, guide villagers to correctly understand the institutional nature of the market access of agricultural land, and reduce the risk of the market access of agricultural land. Through intensify popularization education investment, emphasis on rural collective management construction land market after the ownership of land, is the village collective property rights in the villagers' hands, remove the villagers' land property rights after the market will change, highlight the long-term benefits of rural land, and formulate the corresponding mechanism to ensure that the rural collective land revenue increased steadily and land value after long-term development, reduce the villagers perception of farmland market risk. 


\section{Acknowledgement}

This work was supported by the [2018 Ministry of Education Humanities and Social Science Research Youth Fund Project] under Grant [number18YJC790180]; by the [2019 Guangdong Joint Youth Fund Project] under Grant [number 2019A1515110254]; by the [2019 Guangdong Province General University Characteristic Innovation Project] under Grant [number 2019WTSCX098]; by the [2020 Guangdong Province Education Science "Thirteenth Five-Year Plan" project] under Grant [number 2020GXJK184]; by the [Guangdong Province Philosophy and Social Science Planning 2020 Annual General Project] under Grant [number GD20CYJ33].

\section{References}

[1] Z. Huang, "Construction of the unified urban and rural construction land market: status, mode and problems analysis," Social Science Research, no. 2, 2018.

[2] C. R. Wu, F. Luo, "Research on the market mode of rural collective operating construction land: based on the empirical analysis of Nanhai to Guangdong," Journal of Anhui Agricultural University (Social Science Edition), no. 6, 2019.

[3] J. Li, X. Liao, "The dynamic mechanism of rural collective construction land transfer: based on stakeholder perspective," Agricultural Resources and Regional Planning in China, no. 3, 2017.

[4] L. Feng, Z. Wei, H. Z. Zhi, T. X. De, "Game analysis on driving force of rural collective construction land transfer," Journal of Southwest University (Natural Science Edition), no. 3, 2015.

[5] Y. H. Luo, L. F. Lin, Y. J. Hou, "A new idea of China's rural land transfer mode under collective ownership," China Rural Observation, no. 4, 2016.

[6] Y. P. Ma, "Theory, practice and system improvement of rural collective construction land transfer," Economic Issues, no. 4, 2015.

[7] Y. N. Song, "Research on China's rural land transfer under the background of new urbanization," Economic Issues, no. 2, 2017.

[8] Z. J. Wu, Q. Q. Lin, "Policy evolution and academic debate on rural collective operating construction land," Reform, no. 2, 2014.

[9] S. Y. Wen, "Legal reform of "equal person's city" of collective operating construction land," China Law, no. 4, 2015.

[10] X. H. Cao, "The market entry mode of collective construction land and its legislative choice," Theoretical exploration, no. 2, 2016.

[11] J. Lu, "Empirical analysis and legislative response of collective operating construction land," Legal Business Research, no. 3, 2015.

[12] W. J. Shen, W. Z. Zhang, "Analysis on the distribution of value-added income of collective operating construction land in the market: a case study of Jiangsu province," Modern Management Science, no. 7, 2018.

[13] W. Zhang, "Distribution mechanism of value-added income of rural collective operating construction land: From the perspective of initial transfer of collective operating construction land," Journal of Chengdu University of Technology (Social Science Edition), no. 2, 2016.

[14] B. Zhai, L.T. Liang, "Farmers' cognition and willingness to enter the market for rural collective operating construction land," Arid Land Resources and Environment, no. 10, 2017.

[15] T. Zhang, A. L. Zhang, S. L. Deng, "Market efficiency and influencing factors of rural collective construction land from the perspective of demand side," Resources and Environment in the Yangtze Basin, no. 9, 2019.

[16] T. Zhang, A. L. Zhang, S. L. Deng, "Study on the transaction costs of rural collective construction land market based on Williamson Analytical Paradigm: Supply side analysis of 1872 market transaction data and 372 survey data in Nanhai District," China Land Science, no. 2, 2017.

[17] X. Gao, A. L. Zhang, "The impact of rural collective construction land entering the market on farmers' income," China Land Science, no. 4, 2018. 